\title{
El efecto de agregación entre el consumo de alcohol y la tasa de mortalidad por diabetes mellitus
}

\section{Aggregate level association between alcohol and diabetes mellitus mortality rate}

\author{
Yu. E. Razvodovsky \\ Facultad de Medicina del Estado de Grodno, Bielorrusia \\ Enviar correspondencia a: \\ Yu. E. Razvodovsky. Telf.: +375 01527018 84. Fax: +375 01523353 41. E-mail: razvodovsky@grsmu.by yury_razvodovsky@yahoo.com
}

\section{RESUMEN}

Antecedentes: La diabetes mellitus es un importante tema de salud pública. El consumo de alcohol se considera un factor relevante en el riesgo de diabetes. Objetivo: Calcular el nivel de agregación de bebidas alcohólicas específicas en la tasa de mortalidad por diabetes mellitus. Método: Se analizaron las tendencias de los coeficientes específicos por género de las tasas de mortalidad por diabetes mellitus desde 1981 a 2001 en Bielorrusia en relación con las tendencias de ventas de diferentes tipos de bebidas alcohólicas utilizando análisis de series temporales. Resultados: El análisis sugiere un efecto positivo y estadísticamente significativo de los cambios en la venta per capita de bebidas fuertes (vodka) en la tasa de mortalidad por diabetes entre hombres y mujeres. Conclusión: Este artículo ofrece nuevas evidencias epidemiológicas de la relación del nivel de agregación entre la tasa de mortalidad por diabetes y la venta de bebidas alcohólicas fuertes per capita.

Palabras clave: Venta de alcohol, mortalidad por diabetes, análisis de series temporales, beber compulsivo, Bielorrusia.

\section{ABSTRACT}

Background: Diabetes mellitus is a major public health issue. Alcohol abuse is a factor that has been suggested to be relevant with respect to the risk of diabetes. Purpose: To estimate the aggregate level beverage-specific effect of alcohol on diabetes mellitus mortality rate. Method: Trends in genderspecific coefficients of diabetes mortality rate from 1981 to 2001 in Belarus were analyzed in relation to trends in the level of different types of alcoholic beverages sales per capita by using time series analysis. Results: The analysis suggested a positive and statistically significant effect of changes in strong spirits (vodka) per capita sale on diabetes mortality rate among male and female. Conclusion: This paper presents new epidemiological evidence of aggregate level relation between diabetes mortality rate and strong spirits sale per capita.

Key words: alcohol sale, diabetes mortality, time series analysis, binge drinking, Belarus.
$\mathbf{L}$ a diabetes mellitus es un importante tema de salud pública, cuya prevalencia ha aumentado en las últimas décadas en todo el mundo (Ajani, 2000). Entre el año 2000 y el 2030 se espera en todo el mundo un incremento del $37 \%$ en la prevalencia de la diabetes de tipo 2 (no insulinodependiente) (Kao, Puddey, Boland, Watson y Brancati, 2001). Aparte de la obesidad, la reducción de la actividad física y el consumo de tabaco, hay otros factores de riesgo en el estilo de vida que conducen a la diabetes de tipo 2. El alcohol es un factor relevante en el riesgo de padecer
D iabetes mellitus is a mayor public health issues, its prevalence has raised (in) recent decades world wide (Ajani, 2000). Between 2000 and 2030 , a $37 \%$ increase in the world wide prevalence of diabetes 2 (non-insulin-dependent) is expected (Kao, Puddey, Boland, Watson and Brancati, 2001). Aside from obesity, reduced physical activity, and cigarette smoking, there are few other lifestyle risk factors for type 2 diabetes. Alcohol is a lifestyle factor that also has been suggested to be relevant with respect to the risk of type 2 diabetes (Howard, Arnsten, 
diabetes de tipo 2 (Howard, Arnsten, Gourevitch, 2004; Richardson, Weiss, Thomas y Kerr, 2005). Los efectos diabetogénicos del alcohol incluyen obesidad como consecuencia de un exceso de ingesta calórica, alteración del metabolismo de los carbohidratos, aumento de la resistencia a la insulina, disminución de la tolerancia a la glucosa y de la secreción de insulina, inducción a la pancreatitis y la cirrosis hepática (Avorago y Tiego, 1993; Fleming y Mundt, 2004; Koko, Todorovic, Nikolic, Glisic, Gakic, Lackovic et al., 1995; Suzuki y Tatara, 2003). El consumo abusivo de alcohol incrementa el riesgo de complicaciones médicas, como cetoacidosis, enfermedad vascular periférica, neuropatía, enfermedades del corazón y cerebrovasculares (Fleming y Mundt, 2004; Wannamethee, Shaper, Perry, Alberti, 2002). Recientemente Turner ha demostrado que el consumo nocturno de alcohol aumenta el riesgo de hipoglucemia a la mañana siguiente en pacientes con diabetes de tipo 1 (Turner, Jenkins, Herr, Sherwin y Cavan, 2001). Algunos estudios sobre la relación entre consumo de alcohol y el riesgo de diabetes de tipo 2 publicados en los últimos años han arrojado resultados contradictorios (Ajani, 2000; Carlsson, Hammar, Grill y Kaprio, 2003; Colomb, 1999). En el estudio prospectivo sobre Rancho Bernardo el tertil superior de bebedores varones que consumía > 25 gramos de alcohol al día tenía un riesgo significativamente más alto de desarrollar diabetes de tipo 2 que los bebedores más moderados (Holbrook, Barret-Connor y Wingard, 1990). Los resultados de otro estudio indican que, tras el ajuste de elementos de distorsión potenciales, los hombres de mediana edad que consumían $>21$ bebidas a la semana tenían un 50\% más de probabilidades de desarrollar diabetes de tipo 2 que los que consumían $<1$ bebida a la semana. El riesgo de diabetes entre los hombres de mediana edad que consumían $>14$ bebidas alcohólicas por semana era aproximadamente del $80 \%$ más alto que el de los hombres que no bebían alcohol (Kao et al., 2001). Y así, el incremento del riesgo de diabetes entre hombres se relacionaba fundamentalmente con el consumo de alcohol. Por otro lado, varios estudios prospectivos a gran escala han mostrado asociaciones en forma de $U$ o de $\mathrm{J}$ con la incidencia más baja de diabetes de tipo 2 en sujetos que consumen alcohol moderadamente (Carlsson et al., 2003; Nakanishi, Suzuki y Tatara, 2003; Zilkens, Burke, Watts, Beilin y Puddey, 2003). Howard et al. (2004) han observado una relación no lineal entre el consumo de alcohol y el riesgo de desarrollar diabetes de tipo 2 incluso después de ajustar los potenciales factores de distorsión. En comparación con los no bebedores, los bebedores moderados (que consumen de una a tres bebidas diariamente) tienen un riesgo de diabetes inferior, que oscila entre un 33\% y un $56 \%$. En las personas que consumen más de tres bebidas diariamente aumenta un $43 \%$ el riesgo de diabetes. En un reciente estudio Nakanishi et al. (2003) han demostrado que el riesgo de contraer diabetes disminuía progresivamente de nivel en los bebedores moderados
Gourevitch, 2004; Richardson, Weiss, Thomas and Kerr, 2005). The diabetogenic effects of alcohol include obesity as a result of excess caloric intake, disturbance of carbohydrate metabolism, increase insulin resistance, decrease glucose tolerance and insulin secretion, induction of pancreatitis and liver cirrhosis (Avogaro y Tiego, 1993; Fleming and Mundt, 2004; Koko, Todorovic, Nikolic, Glisic, Cakic, Lackovic, et al., 1995; Suzuki and Tatara, 2003). Alcohol abuse increase the risk for medical complication, such ketoacidosis, peripheral vascular disease, neuropathy, heart disease, and cerebrovascular disease (Fleming and Mundt, 2004; Wannamethee, Shaper, Perry and Alberti, 2002). Recently, Turner reported that evening consumption of alcohol increase the risk of hypoglycemia the next morning in patients with type 1 diabetes (Turner, Jenkins, Herr, Sherwin and Cavan, 2001). Studies on the relationship between alcohol consumption and the risk for type 2 diabetes that have been published during the last few years have reported conflicting results (Ajani, 2000; Carlsson, Hammar, Grill and Kaprio, 2003; Colomb, 1999). In the prospective Rancho Bernardo Study the upper tertile of male drinkers consumed > $25 \mathrm{~g}$ alcohol/day had a significantly higher risk of developing type 2 diabetes compared with the lighter drinkers (Holbrook, BarretConnor and Wingard, 1990). The results of another study suggest that after adjustment for potential confounders middle-aged men who consumed $>21$ drinks/week were $50 \%$ more likely to develop type 2 diabetes compared with men who drank $<1$ drink/ week. The risk of diabetes among middle-aged men who drank $>14$ drink of spirits per week was about $80 \%$ higher than the risk of men who did not drink spirits (Kao et al., 2001). Thus, the increased risk of diabetes among men was predominantly related to spirits consumption. On the other hand, several largescale prospective studies have suggested on $U$ - or $\mathrm{J}$ - shaped association, with the lowest incidence of type 2 diabetes in subjects with moderate alcohol consumption (Carlsson et al., 2003; Nakanishi, Suzuki and Tatara, 2003; Zilkens, Burke, Watts, Beilin and Puddey, 2003). Howard et al. reported a nonlinear relation between alcohol consumption and risk for development of type 2 diabetes even after adjustment for potential confounders factors. Compared with nondrinkers, moderate drinkers (those who consume one to 3 drinks daily) have $33 \%$ to $56 \%$ lower risk for diabetes. Persons who consume more than 3 drinks daily have up to a $43 \%$ greater risk for diabetes (Howard et al,. 2004). In a recent study Nakanichi et al. reported that the risk for development of diabetes decrease progressively up to level of moderate drinking (23,0-45,9 g ethanol/day) and increase in 
(23,0-45,9 grs. etanol/día) y aumentaba en los grandes bebedores (>69,0 grs. etanol/día). Varios estudios que observan el papel del modelo de beber en relación con el riesgo de sufrir diabetes de tipo 2 indican que el beber compulsivo aumenta sustancialmente el riesgo (Conigrave, Hu, Camargo, Stampfer, Willett y Rimm, 2001). En la línea de estos hallazgos pensamos que beber compulsivamente licores fuertes redunda en una estrecha asociación entre la agregación de mortalidad por diabetes y alcohol. Para comprobar esta hipótesis se analizaron las tendencias en los coeficientes por género de la tasa de mortalidad por diabetes (tipo 1 y tipo 2) entre 1981 y 2001 en Bielorrusia en relación con las tendencias del nivel de ventas per capita de diferentes clases de bebidas alcohólicas, utilizando análisis de series temporales.

\section{MATERIALESY MÉTODOS}

Todos los datos que se ofrecen en el artículo se han recogido de los informes anuales del Ministerio de Estadística de Bielorrusia de 1981 a 2001. Los niveles de mortalidad se presentan al porcentaje de 1 a 100.000 de población. Las ventas de alcohol per capita (en litros de alcohol puro) se calculan sobre la base de las ventas totales de alcohol que aparecen en las estadísticas de ventas, divididas por el total de la población. Los análisis estadísticos (correlación, regresión, análisis de intervalos distribuidos) se realizaron con el paquete "Statistica 7". Se suele admitir que las correlaciones bivariadas entre dos series temporales sucesivas son espurias debido a las fuentes comunes de tendencias y autocorrelaciones (Norstrom y Skog, 2001). Por tanto, para reducir el peligro de obtener una relación falsa entre dos variables con tendencias comunes, han de eliminarse las tendencias (Box y Jenkins, 1976). El proceso de eliminación de la variación sistemática en las series temporales previo al examen de las relaciones causales potenciales se denomina preblanqueamiento. Los residuos de una serie temporal estadísticamente adecuada se distribuyen como un proceso de ruido blanco. Muchas veces la serie temporal exige una transformación logarítmica para estabilizar la varianza. Un modelo logarítmico se ha utilizado en el presente estudio. Para obtener invariabilidad utilizamos la técnica de mínimos cuadrados. También se ha recurrido al análisis de intervalos distribuidos polinómicos y espontáneos para estimar la relación de los intervalos (esto es, para evaluar la estructura de intervalos) entre el nivel de ventas de bebidas de fuerte gradación como variable independiente y la tasa de mortalidad por diabetes como variable dependiente. heavy drinkers (> 69,0 g ethanol/day) (Nakanishi et al., 2003). Several studies that addressed the role of drinking pattern in relation to risk of type 2 diabetes suggest that binge drinking substantially increased the risk (Conigrave, Hu, Camargo, Stampfer, Willett and Rimm, 2001). In line with these findings we assume that binge drinking of strong spirits would results in a close association between diabetes mortality and alcohol at the aggregate level. To test this hypothesis trends in gender-specific coefficients of diabetes (type 1 and type 2) mortality rate from 1981 to 2001 in Belarus were analyzed in relation to trends in the level of different types of alcoholic beverages sales per capita employing time series analysis.

\section{MATERIALS AND METHODS}

All data provided in the article are taken from the Ministry of Statistics of Belarus annual report from 1981 to 2001. The levels of mortality are presented at the rate of 1 to 100.000 of population. Sales of alcohol per capita (in litres of pure alcohol) are estimated on the basis of the total alcohol sales as determined by sales statistics, divided by the total population. The statistical analysis (correlation, regression, distributed lags analysis) were conducted with the package "Statistica 7". It is generally agreed that bivariate correlations between two row time-series are spurious due to common sources of trends and autocorrelation (Norstrom and Skog, 2001). Therefore, in order to reduce the risk of obtaining a spurious relation between two variables that have common trends, the trends should be removed (Box and Jenkins, 1976). The process of removing systematic variation within time series prior to the examination of potential causal relationships is referred as pre-whitening. The residuals of a statistically adequate time series are distributed as a white noise process. Often the time series first requires log transforming to stabilize the variance. Therefore, a logarithmic model has been used in the present study. In order to achieve stationarity we used least square technique in this study as well. Unconstrained polynomial distributed lags analysis has been also used to estimate lagged relationship (i.e. to assess the lag structure) between the level of strong spirits sale as independent variable and the diabetes mortality rate as dependent. 


\section{RESULTADOS}

Según la estadística oficial la tasa de mortalidad por diabetes aumentó un 3.3 (de 1.5 a 4.9 por cada cien mil personas) entre hombres y un 3.4 (de 2.4 a 8.2 por cada cien mil personas) entre mujeres en el período comprendido entre 1981 y 2001. Las tendencias de la tasa de mortalidad por diabetes en hombres y mujeres y la venta de bebidas alcohólicas per capita se representan en las figuras 1 y 2 . Como se puede ver, hay una notable tendencia ascendente en la mortalidad por diabetes hasta el principio de los años noventa, seguida por una estabilización. Las pruebas gráficas indican una clara asociación entre las tendencias de mortalidad por diabetes entre hombres y mujeres y la venta de vodka. El análisis de correlaciones de Pearson muestra la íntima relación entre el nivel de venta de bebidas alcohólicas per capita y la tasa de mortalidad por diabetes (tabla 1). Simultáneamente, apenas se observa correlación alguna entre el nivel total de venta de alcohol y la tasa de mortalidad por diabetes. Del mayor interés es el hecho, comprobado durante el análisis, de que hay una correlación negativa entre

\section{RESULTS}

According to official statistics, the diabetes mortality rate increased 3.3 fold (from 1.5 to 4.9 per 100.000 of population) among male and 3.4 fold (from 2.4 to 8.2 per 100.000 of population) among female in the period from 1981 to 2001. The trends in male and female diabetes mortality rate and the level of spirits sale per capita are displayed in figure 1-2. As we can see, there is a marked upward trend in diabetes mortality until the beginning of the 1990s, followed by stabilization. The graphical evidence suggests quite strong association between trends of male and female diabetes mortality and vodka sale. The Pearson's correlation analysis suggests the strong relationship between the level of spirits sale per capita and diabetes mortality rate (table 1). At the same time, hardly any correlation is observed between the total level of alcohol sale and the diabetes mortality rate. Of interest may be the fact, found out during the analysis, that there is a negative

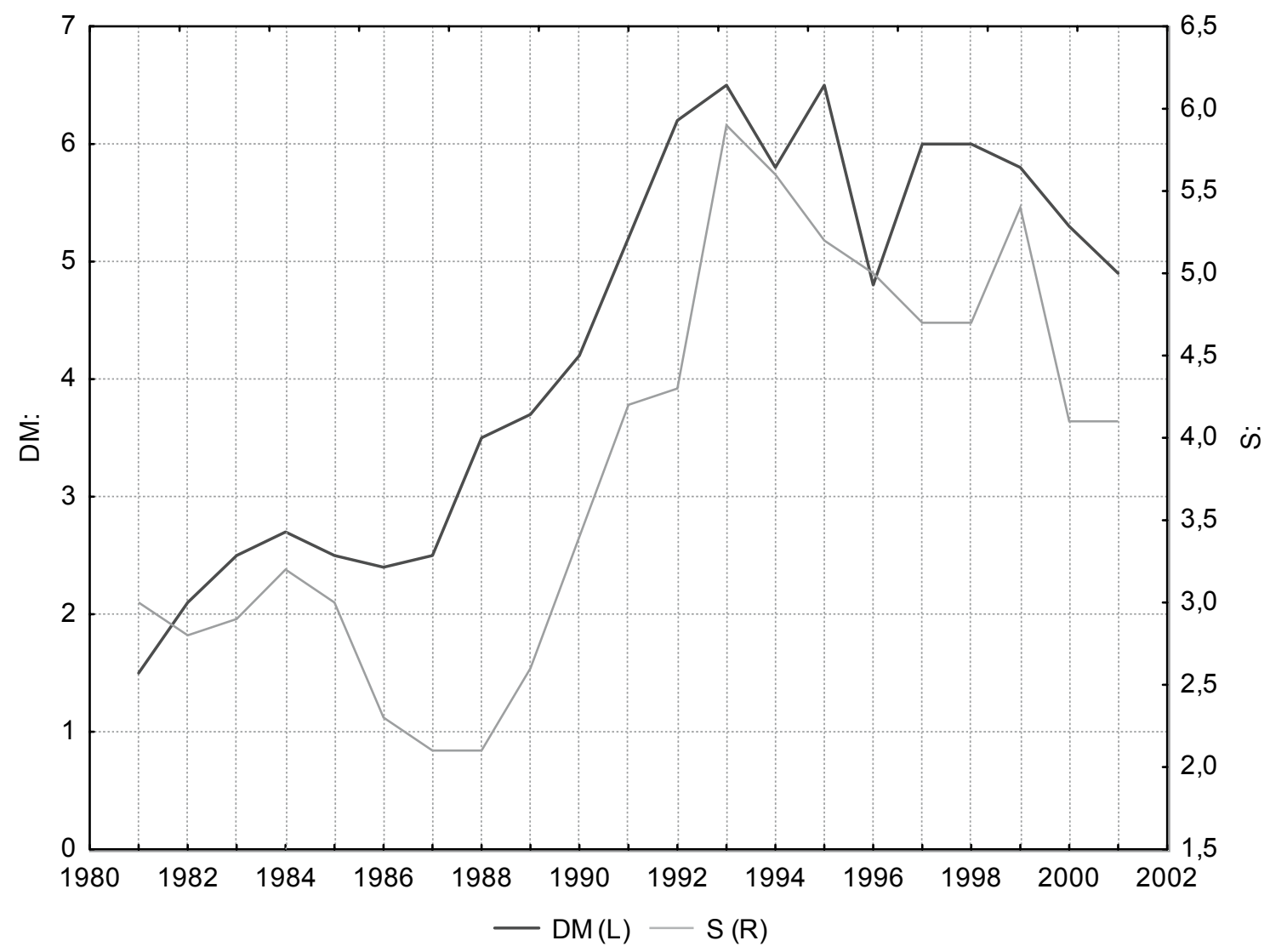

Figura 1. Dinámica de venta de vodka per capita (S) y tasa de mortalidad por diabetes en hombres (DM) en Bielorrusia en 1981-2001.

Dynamics of vodka sale per capita (S) and male diabetes mortality rate (DM) in Belarus in 1981-2001. 


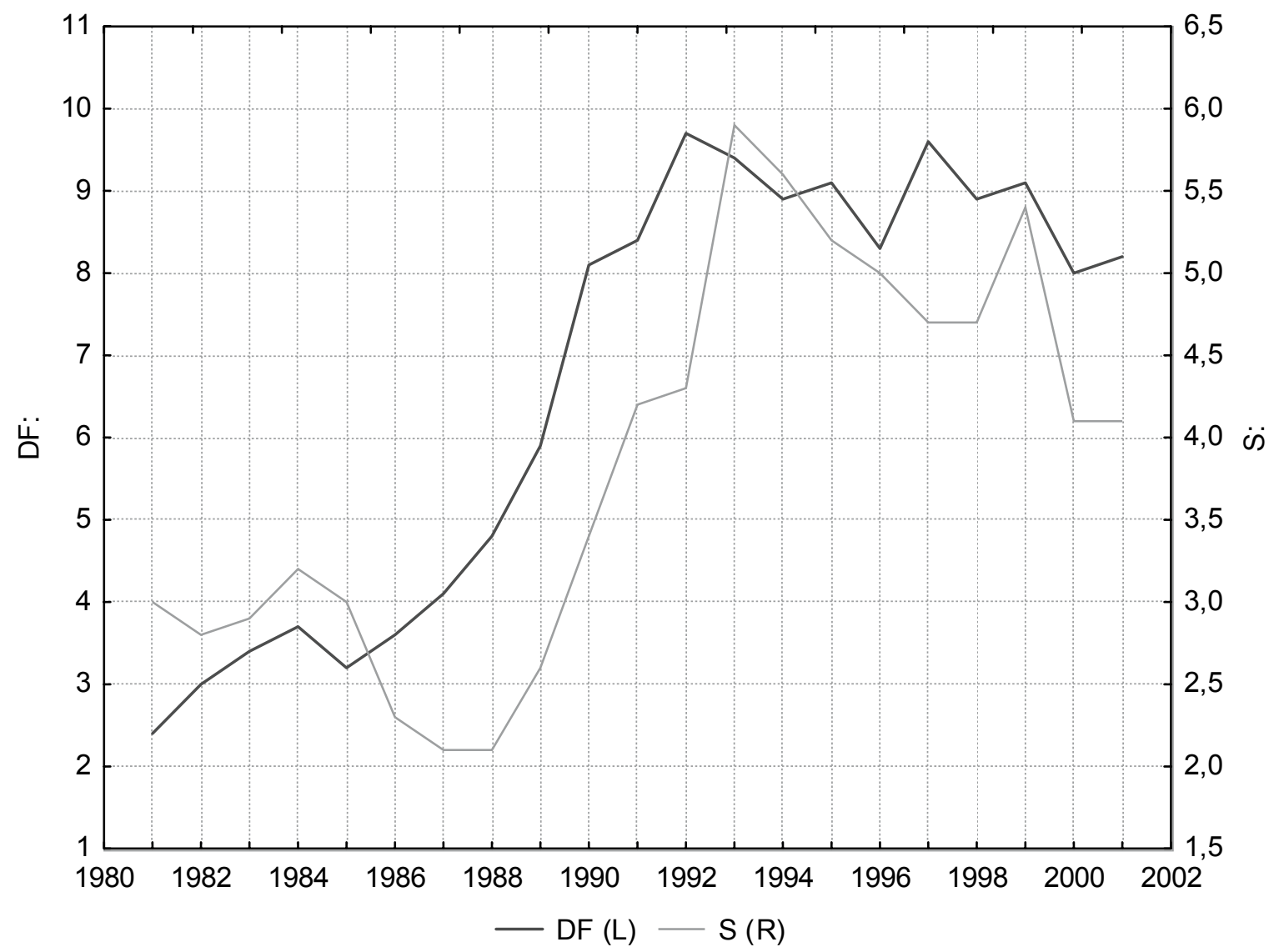

Figura 2. Dinámica de venta de vodka per capita (S) y tasa de mortalidad por diabetes en mujeres (DF) en Bielorrusia en 1981-2001.

Dynamics of vodka sale per capita (S) and female diabetes mortality rate (DF) in Belarus in 1981-2001.

Tabla 1. Correlaciones de la tasa de mortalidad por diabetes y consumo de alcohol, en hombres y mujeres. Table 1. Correlations of diabetes mortality rate and use of alcohol in males and females.

\begin{tabular}{|l|c|c|c|c|c|c|c|c|}
\hline & \multicolumn{2}{|c|}{$T$} & \multicolumn{2}{c|}{$S$} & \multicolumn{2}{c|}{ W } & \multicolumn{2}{c|}{ B } \\
\cline { 2 - 10 } & $r$ & $p$ & $r$ & $p$ & $r$ & $p$ & $r$ & $p$ \\
\hline DM hombres & $-0,03$ & 0,92 & 0,87 & 0,00 & $-0,59$ & 0,01 & $-0,78$ & 0,00 \\
\hline DF mujeres & $-0,07$ & 0,79 & 0,84 & 0,00 & $-0,62$ & 0,01 & $-0,78$ & 0,00 \\
\hline
\end{tabular}

DM - tasa de mortalidad por diabetes en hombres, DF - tasa de mortalidad por diabetes en mujeres, $T$ - nivel total de venta de alcohol, S - nivel de venta de bebidas fuertes (vodka), W - ventas de vino, B - ventas de cerveza

DM - male diabetes mortality rate, DF - female diabetes mortality rate, $T$ - total level of alcohol sale, $S$ - level of strong spirits (vodka) sale, $W$-wine sale, $B$ - beer sale.

las tasas de mortalidad por diabetes entre hombres y mujeres y el nivel de venta de cerveza y vino per capita. Como el coeficiente de correlación entre variables como la tasa de mortalidad por diabetes y el nivel de venta de vodka per capita se acerca a 1, en análisis posteriores se aplicó el modelo de regresión lineal. La relación entre el nivel de venta de bebidas alcohólicas y la tasa de mortalidad por diabetes entre hombres se puede describir con la ecuación de correlation between male and female diabetes mortality rates and the level of beer and wine sales per capita. As the correlation coefficient between such variables as the diabetes mortality rate and the level of vodka sale per capita is close toward 1, linear regression model was applied in further analysis. The relationship between the level of spirits sale and the male diabetes mortality rate can be described by the equation of linear regression $y=B_{0}+B_{1}{ }^{*} x$, were $B_{0}$ 
regresión lineal $y=B_{0}+B_{1}{ }^{*} x$, donde $B_{0}=0.3 ; B_{1}=1.2$; $\mathrm{R}^{2}=0,74 ; \mathrm{p}<0.000, \mathrm{y}$ - tasa de mortalidad; $\mathrm{x}$ - nivel de venta de bebidas alcohólicas per capita. La ecuación de regresión lineal describe el setenta y cuatro por cien de la dispersión total del índice de mortalidad por diabetes y se caracteriza por su alta validez. La relación entre la tasa de mortalidad por diabetes entre mujeres y el nivel de venta de vodka per capita también se puede describir con la ecuación de regresión lineal y $=1.86$ - 0.3; $R^{2}=0.71 ; p<0.000$. Como existe un componente no lineal en dos series, los datos se transformaron por medio de una función logarítmica. Además, utilizamos la técnica de mínimos cuadrados para transformar las dos series en un nuevo conjunto de observaciones. Este modelo posee criterios diagnósticos estacionarios, a saber residuos distribuidos como un proceso de ruido blanco. Para calcular la relación retardada entre dos series temporales de preblanqueamiento utilizamos el análisis de intervalos distribuidos (tablas 2-3). El análisis indica la presencia de una asociación estadísticamente significativa entre la venta de vodka per capita y la tasa de mortalidad por diabetes entre hombres en el intervalo cero (coeficiente de regresión 0.67; $p<0.002$ ) y entre mujeres en el intervalo cero (coeficiente de regresión 0.73; $p<0.002$ ).
$=0.3 ; B_{1}=1.2 ; R^{2}=0,74 ; p<0.000, y-$ mortality rate; $x$ - level of spirits sale per capita. The equation of linear regression describes 74 per cent of the total dispersion of the diabetes mortality index and is characterized by high validity. The relationship between the female diabetes mortality rate and level of vodka sale per capita also can be described by the equation of linear regression $y=1.8-0.5 ; R^{2}$ $=0.71 ; p<0.000$. As there is nonlinear component in two series, the data were transformed by means of logarithmic function. Further we used least squares technique to transform two series into a new set of observations. This model meet diagnostic criterion of stationarity; i.e. residuals distributed as a white noise process. In order to estimate a lagged relationship between two pre-whitening time series we used distributed lags analysis (table 2-3). The analysis indicate the presence of statistically significant association between vodka sale per capita and diabetes mortality rate among male at zero lag (Regres Coeff 0.67; $p<0.002$ ) and among female at zero lag (Regres Coeff 0.73; $p<0.002$ ).

Tabla 2. Resultados de los análisis de intervalos distribuidos. Variable independiente - venta de vodka per capita; variable dependiente - tasa de mortalidad por diabetes en hombres.

Table 2. The results of distributed lags analysis. Independent variable - vodka sale per capita, dependent variable - male diabetes mortality rate.

\begin{tabular}{|c|c|c|c|c|}
\hline $\begin{array}{c}\text { Intervalo } \\
\text { Lag }\end{array}$ & $\begin{array}{c}\text { Coeficiente de } \\
\text { Regression } \\
\text { Regression } \\
\text { Coefficcient }\end{array}$ & $\begin{array}{c}\text { Error standard } \\
\text { Standard error }\end{array}$ & $\mathrm{t}$ & $\mathrm{p}$ \\
\hline 0 & 0,67 & 0,22 & 2,42 & 0,002 \\
\hline 1 & $-0,01$ & 0,38 & $-0,03$ & 0,970 \\
\hline 2 & $-0,17$ & 0,40 & $-0,43$ & 0,673 \\
\hline 3 & $-0,25$ & 0,30 & $-0,84$ & 0,412 \\
\hline
\end{tabular}

Tabla 3. Resultados de los análisis de intervalos distribuidos. Variable independiente- venta de vodka per capita; variable dependiente - tasa de mortalidad por diabetes en mujeres.

Table 3. The results of distributed lags analysis. Independent variable - vodka sale per capita, dependent variable - female diabetes mortality rate.

\begin{tabular}{|c|c|c|c|c|}
\hline $\begin{array}{c}\text { Intervalo } \\
\text { Lag }\end{array}$ & $\begin{array}{c}\text { Coeficiente de } \\
\text { regresión Regression } \\
\text { coefficient }\end{array}$ & $\begin{array}{c}\text { Error standard } \\
\text { Standard error }\end{array}$ & $\mathrm{t}$ \\
\hline 0 & 0,73 & 0,28 & 2,56 & 0,002 \\
\hline 1 & $-0,15$ & 0,39 & $-0,38$ & 0,707 \\
\hline 2 & $-0,21$ & 0,41 & $-0,50$ & 0,619 \\
\hline 3 & $-0,32$ & 0,31 & $-1,04$ & 0,314 \\
\hline
\end{tabular}




\section{DISCUSIÓN}

El análisis de series temporales indica una relación positiva entre la venta de vodka y la mortalidad por diabetes en el intervalo cero. Defendemos que en este caso la variable independiente influye en la dependiente y no hay pruebas de que existan relaciones retardadas entre las dos series temporales. Sin embargo, este hecho se puede interpretar como que la venta de vodka y la tasa de mortalidad se ven influidas por una variable de distorsión. Existen cada vez más pruebas científicas de que la angustia psicosocial producto de cambios sociales, políticos y económicos radicales influyó de forma determinante en el elevado incremento del consumo de alcohol y las crisis de mortalidad en las repúblicas de la antigua Unión Soviética a principios de los años noventa (Gavrilova, Semyonova, Evdokushkina y Gravrilov, 2000; Stone, 2000). Varios estudios epidemiológicos y experimentales muestran un claro vínculo entre la incidencia de la diabetes y el estrés. En modelos de animales con diabetes insulinodependiente, la exposición al estrés reiterado aumentaba la incidencia de la diabetes (Lehman, Rodin, Mcewen y Brinton, 1991). Entre los niños la inestabilidad familiar aumenta la incidencia y severidad de la diabetes insulinodependiente (Hagglof, Blom, Dahlduist, Lonnberg y Sahlin, 1991). El estrés crónico se ha relacionado con el desarrollo de la resistencia a la insulina como un factor de riesgo de la diabetes no insulinodependiente en otro estudio (Raikkonen, Keltikangas-Jarvinen, Adlercretz y Hautenen, 1996). Y así, la angustia psicosocial puede ser un importante factor subyacente en el notorio incremento de la mortalidad por diabetes y de la venta de vodka a finales de los años ochenta y principios de los noventa. Al respecto hay que subrayar que la dinámica de la diabetes encaja con el típico modelo de relación con el estrés: gran crecimiento a finales de los años ochenta y principios de los noventa (período agudo) y estabilización a finales de los noventa (período de adaptación). Sería interesante examinar en posteriores análisis el impacto de elementos potenciales de distorsión en la relación entre diabetes y alcohol. Debemos admitir que una seria limitación de este análisis es el pequeño número de observaciones.

El resultado del presente estudio indica que la mortalidad por diabetes tiende a ser más producto de los cambios en las ventas de bebidas alcohólicas fuertes per capita que en el nivel total de venta de alcohol en los países en los que la cultura del beber favorece una forma de beber orientada a la embriaguez. Este estudio apoya asimismo la idea de que el beber compulsivo es un factor de riesgo de mortalidad por diabetes a nivel de la población.

\section{DISCUSSION}

The time series analysis suggests a positive relationship between vodka sale and diabetes mortality at zero lag. We argue that in this case the independent variable is influencing the dependent one and there is no evidence of lagged relationships between the two time series. However, this fact may be interpreted in a way that vodka sale and diabetes mortality are being influenced by a confounder variable. There is growing body of research evidence that psychosocial distress resulting from dramatic social, economic and political changes were main determinant of sharp increases of alcohol consumption and mortality crisis in the former Soviet republics in early 1990-s (Gavrilova, Semyonova, Evdokushkina, Gavrilov, 2000; Stone, 2000). Several epidemiological and experimental studies suggest a close link between the incidence of diabetes and the stress. In animal model of insulin-dependent diabetes, an exposure to repeated stress increased the incidence of diabetes (Lehman, Rodin, Mcewen, and Brinton, 1991). In children, family instability increases the incidence and severity of insulin-dependent diabetes (Hagglof, Blom, Dahlduist, Lonnberg and Sahlin, 1991). Chronic stress has been linked to the development of insulin resistance, as a risk factor for non-insulin dependent diabetes in another study (Raikkonen, Keltikangas-Jarvinen, Adlercretz and Hautenen, 1996). So, psychosocial distress may be an important underlying factor in the sharp increase of diabetes mortality and vodka sales in late 1980-s early 1990-s. In this respect it is important to note that dynamics of diabetes mortality fits the typical stressrelated pattern: dramatic growth in late 1980-s - early 1990-s (acute stage) and stabilization in late 1990-s (stage of adaptation). Therefore it would be interesting to examine the impact of potential confounders on diabetes-alcohol relationship in further analysis. Here we should also admit that a serious limitation of this analysis is the small number of observations.

So, the outcome of the present study suggests that diabetes mortality tends to be more responsive to changes in strong spirits sale per capita than in total level of alcohol sale in the countries where drinking culture favors an intoxication-oriented drinking pattern. This study also supports the idea that binge drinking is a risk factor on diabetes mortality at the population level. 


\section{REFERENCIAS / REFERENCES}

Ajani. U. A., Hennekers, C. H., Spelsberg, A., Manson, J. E. (2000): Alcohol consumption and risk of type 2 diabetes mellitus among US male physicians. Arch Intern Med, 160: 1025-1030.

Avogaro, A., Tiego, A. (1993): Alcohol, glucose metabolism and diabetes. Diabete Metab Rew, 9: 129-146.

Box, G. E. P., Jenkins, G. M. (1976): Time Series Analysis: forecasting and control. London. Holden-Day Inc.

Carlsson, S., Hammar, N., Grill, V., Kaprio, J. (2003): Alcohol consumption and incidence of type 2 diabetes. Diabetes Care, 26:2785-2790.

Colomb, B. A. (1999): Should patients with diabetes drink to their health? JAMA, 282:279-280.

Conigrave, K. M., Hu, B. F., Camargo, C.A., Stampfer, M. J., Willett, W. G., Rimm, E. B. (2001): A prospective study of drinking patterns in relation to risk of type 2 diabetes among men. Diabetes, 50:2390-2395.

Fleming, M., Mundt, M. (2004): Carbohydrate-deficients transferring: validity of a new alcohol biomarker in a sample of patients with diabetes and hypertension. The Journal of the American Boards of Family Practice, 17: 247-255.

Gavrilova, N. S., Semyonova, V. G., Evdokushkina, G. N., Gavrilov, L. A. (2000): The response of violent mortality to economic crisis in Russia. Population Research and Policy Review, 19: 397-419.

Hagglof, D., Blom, L., Dahlduist, G., Lonnberg, G., Sahlin, B. (1991) The swedish childhood diabetes study: indications of severe psychological stress as a risk factor for type 1 diabetes mellitus in childhood. Diabetologia. 34; 579-583

Holbrook, T. L., Barret-Connor, E., Wingard, D.L. (1990): A prospective population-based study of alcohol use and non-insulin-dependent diabetes mellitus. Am J Epidemiol, 132: 902-909.

Howard, A. A., Arnsten, J. H., Gourevitch, M. N. (2004): Effect of alcohol consumption on diabetes millitus. Ann Intern Med, 140:211-219.

Kao, W. H., Puddey, I. B., Boland, L. L., Watson, R. L., Brancati, F. L. (2001): Alcohol consumption and the risk of type 2 diabetes mellitus: atherosclerosis risk in communities study. Am J Epidemiol, 154: 748-757.
Koko, V., Todorovic, V., Nikolic, J. A., Glisic, R., Cakic, M., Lackovic, V., Petronijevic, L., Stojkovic, M., Varagic, J., Janic, B., et al. (1995): Rat pancreatic betta-cells after chronic alcohol feeding: a morphometric and fine structural study. Histol Histopathol, 10:325-337.

Lehman, C., Rodin, J., Mcewen, B. C., Brinton, R. (1991) Impact of environmental stress on the expression of insuline-dependent diabetes mellitus. Behav Neurosci, 105: 241-245

Nakanishi, N., Suzuki, K., Tatara, K. (2003): Alcohol consumption and risk for development of impaired fasting glucose of type 2 diabetes in middle-aged Japanese men. Diabetes Care, 26: 48-54.

Norstrom, T., Skog, O. J. (2001): Alcohol and mortality: methodological and analytical issue in aggregate analysis. Addiction, 96: 5-17.

Raikkonen, K., Keltikangas-Jarvinen, L., Adlercretz, H., Hautenen, A. (1996). Psychosocial stress and the insulin resistance syndrome. Metabolism. 45; 1533-1538.

Richardson, T., Weiss, M., Thomas, P., Ker,r D. (2005): Influence of evening alcohol on risk of hypoglycemia in patients with type 1 diabetes. Diabetes Care, 28:18011802.

Stone, R. (2000): Stress: The invisible hand in Eastern Europe's death rates. / R. Stone // Science, 288: 17321733

Suzuki, K., Tatara, K. (2003): Alcohol consumption and risk for development of impaired fasting glucose or type 2 diabetes in middle-aged Japanese Men. Diabetes Care, 26: $45-48$

Turner, B. C., Jenkins, E., Herr, D., Sherwin, R. S., Cavan, DA. (2001): The effect of evening alcohol consumption on next-morning glucose control in type 1 diabetes. Diabetes Care, 24: 1888-1893.

Wannamethee, S. G, Shaper, A. G., Perry, I. J., Alberti, K. G. (2002): Alcohol consumption and the incidence of type 2 diabetes. J Epidemiology Community Health, 56:542548.

Zilkens, R. R., Burke, V., Watts, G., Beilin, L. J., Puddey, I. B. (2003): The effect of alcohol intake on insulin sensitivity in men. Diabetes Care, 26:608-612. 